\title{
The Use of Javanese by Society of Keraton Surakarta Hadiningrat
}

\author{
Eka Susylowati ${ }^{1 *}$ \\ ${ }^{1}$ Universitas Surakarta, Surakarta, Indonesia
}

\begin{tabular}{|l|l|l|}
\hline Contact: & Eka Susylowati & esusylowati@gmail.com \\
\hline
\end{tabular}

\begin{abstract}
This research aims to find out Javanese form and its relationship between locutor and interlocutor. This research is qualitative in nature. The location of this research is in the Surakarta Hadiningrat palace. The language variation used in this research is daily activity and official palace ceremonies. The data are derived from the verbal interaction among society of kraton in formal and informal situation. The data were collected by recording, observing, interviewing technique. The analysis data used Hymes, ethnography method communication. The result of the research shows that the Javanese forms consists of ngoko, madya, krama, krama inggil, kedhaton and even Indonesian. Related to the relation between locator and interlocutor, the form of Javanese affected by the horizontal and vertical relation accordance with social status in the palace. The pattern of using ngoko, madya, krama has changed, moreover when Indonesian has been their repertoire.
\end{abstract}

\author{
KEYWORDS: \\ Javanese; \\ Society of Keraton; \\ Keraton Surakarta \\ Hadiningrat.
}

\section{Introduction}

Indonesia consists of many ethnic and languages. Language use is strongly related to society. The language shows the identity of the locutor in the social environment. The Javanese has its own character, those are culture and identity. The identity of culture has begun since the kingdom era, however, in the globalization the identity has much changed. It is influenced by many factors; one of the factors is foreign culture so that the Javanese culture has much degradation. In the society of kraton, such as Surakarta Hadiningrat palace, the group of social is formed by feeling of togetherness in the society. Thus, every social group has different habitual traits; it covers the use of language. In daily life, the society of kraton is used the Javanese speech levels 
from ngoko, madya, krama, krama inggil and kedhaton language. The communication among the society of kraton must be careful because of there is different stratification in the Surakarta Hadiningrat palace so that the choice of words must be careful when they speak among society in the palace. It seems that unggah-ungguhing basa or speech levels are well maintained. Poedjosoedarmo $(1979$, p. 3) said that speech levels are different variations language which is determined by the different of politeness between locutor and interlocutor.

In the Surakarta Hadiningrat palace has unique language, it is called kedhaton language, meanwhile in the Yogyakarta Hadiningrat palace called bagongan language. At the moment, kedhaton language is used to communicate among society in the palace on formal situation when official palace ceremonies, however, the use of kedhaton language is not known by many people because it is used unique lexicon, such as pakenira 'you', manira 'l', enggeh 'Yes', and etc. The sociolinguistic research on the use of language has been conducted by many researchers, namely (Bastiar, Islamiah, 2018; Dwivedi, 2016; Erni Zuliana, 2016; Fahmee \& Fung, 2016; Fithriyah Nurunnisa' Al, 1993; Marlina Maros, 2016; Yusuf, Fata, \& Chyntia, 2018). In the palace has many interesting to investigate, especially in communication system. It is necessary known that Javanese speech levels from ngoko, madya, krama, krama inggil, kedhaton language and even Indonesian used by the society of kraton. From the reasons mentioned above, the researcher is interested in investigating more detail about the form of Javanese used by society in the Surakarta Hadiningrat palace.

The use of Javanese is strongly related to unggah-ungguhing basa (speech levels), suba-sita (politeness) and trap silo uda negara (position). Basically there are two levels in Javanese, namely ngoko (low level) and krama (high level). The level of ngoko is considered a rough level. It is used in a situation of intimacy, though it develops into the sense of humiliation, a person considered to be a lower social status than the speaker or to a person who is 
younger than the speaker or to a person of the same social status whom the speaker knows well. The level of krama is the level of honour and respect, it is considered as alus or halus in Indonesian. It is used to a person who is older than speaker or to a person whom the speaker does not know well.

There are variants based on the two levels mentioned, namely ngoko andhap (low ngoko), antya basa (middle ngoko), wredha krama (old krama), kramantara (middle krama) and basa madya (middle language). Between ngoko and krama, there is another differentiation, namely basa madya (middle language). The following all of them have variants, namely : Krama consists of mudha krama (young krama), kramantara (middle krama), wredha krama (old krama), madya consists of madya-krama (high madya), madyantara (middle krama), madya-ngoko (low madya), ngoko consists of basa-antya (high ngoko), antya-basa (middle ngoko), ngoko-lugu (low ngoko). Kedhaton language is an exclusive language which is used to communicate by society in the palace. The use of Javanese language in formal and informal situation in the palace (kraton) is a proof that the society of kraton loyal maintains their local language in the globalization era.

\section{Method}

The research is classified by a descriptive qualitative because it describes the form of the language. The location of this research is in Surakarta Hadiningrat palace because it is a center of Javanese culture, as the center of Javanese culture; speech levels are very important and dominant. The researcher observed society of kraton speechin daily life and palace official ceremonies as source of data. The source of data consists of respondent, informant, activity and document. The number of respondent in the research is 20 (twenty) consist of abdidalem, sentana dalem, putra dalem, putri dalemeither man or women who able to master language and Javanese culture that his/her own. The researcher has chosen as informant consists of pengageng kraton lead of kraton', namely Dra. Gusti Kangjeng Raden (GKR). Wandhansari is the leader of 
Sasana Wilapa 'centre of secretariat office' and Kangjeng Gusti Pangeran Haryo (KGPH). Puger, B.A, as a leader of Sasanapustaka 'library of kraton'. Abdidalem consists of Kangjeng Raden Aryo (KRAr). Winarnokusuma as public relation of Surakarta Hadiningrat palace, Kangjeng Raden Aryo Tumenggung (KRAT). Pudjodiningrat and Kangjeng Raden Aryo Tumenggung (KRAT). Budayaningrat as practision in palace official ceremonies. The researcher observed the use of Javanese used by society in social interaction in daily life and official palace ceremonies in the Surakarta Hadiningrat palace. The researcher found out archive or old manuscript which related to kedhaton language which is taken from Sasanapustaka.

The sample is chosen from society of kratonspeech on formal and informal situation. The researcher observed by following the activity either formal (working situation, palace official ceremonies, such as Grebegceremony, Wiyosan Jumenengandalem 'the coronation Anniversary of the King) or nonformal situation (casual conversation) in the palace. In dept interview is used by the researcher to obtain the data about the form and factor-factor that influenced the use of Javanese used by society of kraton Surakarta Hadiningrat.The researcher recorded society of kraton conversation by using handphone or video tape then it is transcript into orthographies. The data is analyzed by using contextual-sociolinguistics approach, it means that it is important to decide social context, such as who, which, when, whom, where, and how by using speech component concept stated by Hymes (1974) calling acronym of SPEAKING.

\section{Result}

The society of Surakarta Hadiningrat palace used Javanese speech levels from ngoko, madya, krama, krama inggil, kedhaton language and even Indonesian. The location of abdidalem conversation covers Sasana Wilapa 'a place as a centre of palace secretary, Sasana Sewaka 'a place which is used as the coronation Anniversary of the King, Sasana Hondrowina 'a place which is used 
for eating the guests of the King, Kartipradja 'a place which manages abdidalem and Agung Mosque 'a place which is used as Grebeg ceremony. Topic of speaking covers daily activity, salary, Kirab Malam 1 Sura, Grebeg ceremony, Tingalan Wiyosandalem 'the coronation Anniversary of the King', Mahesa Lawung.

The level of ngoko is used by a person speaking to another person who is known intimately by the speaker, a person whose rank of nobility is lower, a person whose social status is lower. Madya is classified by middle level between ngoko and krama.The level of krama is used by a person speaking to another person whose rank of nobility is higher, a person whom the speaker does not know intimately, a person of older age, a person with high reputation or respect, a person who higher social status. Krama inggil is used by a person with high reputation. Usually, krama inggil (high krama) is used by the people in the palace. Kedhaton language is an exclusive language is used by certain people, situation and place. In other word, kedhaton language is an old language is used in the Surakarta Hadiningrat palace.

\section{Discussion}

The form of the use Javanese by society of keraton is as follows:

\section{Ngoko}

The level of ngoko is used by a person speaking to another person who is known intimately by the speaker, a person whose rank of nobility is lower, and a person whose social status is lower. The following is an example the conversation among abdi dalem Lurah in the Surakarta Hadiningrat palace.

Such example the conversation in the table 1 happens in front of Sasana Sewaka on formal situation. The level of ngoko is used by abdidalem Lurah because they know well so those between of them have not been social distance. It shows that the relationship abdidalem Lurah is classified horizontal relation. In other word, they are the same position. Ngoko level is signed by affix di-such as the word 'dienjah-enjah. The conversation above is called ngoko 
lugu. The aim of speaking is cleaning the palace. Its' contain of conversation is cleaning the palace.

Table 1. Conversation in Javanese Ngoko

\begin{tabular}{|c|c|c|c|}
\hline Type & Name & Javanese & English \\
\hline Data 1 & Lurah & $\begin{array}{l}\text { "wa...Pakdhe Kampret nyapu dienjah- } \\
\text { enjah." } \\
\text { "Kene lho, kowe tekan kono arep golek } \\
\text { apa?" } \\
\text { "Yo" }\end{array}$ & $\begin{array}{l}\text { "wa...Uncle Kampret is sweeping by } \\
\text { scattered." } \\
\text { "come here, what whould you get there?" } \\
\text { "Yes" }\end{array}$ \\
\hline
\end{tabular}

\section{Madya}

Madya is classified by middle level between ngoko and krama. The following is the conversation abdidalem Lurah to abdidalem Panewu is used madya level as follows.

Table 2. Conversation in Javanese Madya

\begin{tabular}{llll}
\hline Type & Name & Javanese & English \\
\hline Data 2 & Lurah & "niki kraton" & "This is a palace"' \\
& & "sesuk sore niki, malem jumat" & "'tomorrow on Friday evening" \\
& & "nggih, benjing-enjing sonten jam tiga, & "Yes, by the end of three afternoon, you \\
& njenengan sampun tindak alun-alun." & will have arrived at field" \\
& Panewu & "O, inggih. Alun-alun mriko napa mriki?" & "Yes. Is this field or that?" \\
& Lurah & "nggih. Alun-alun Kidul nggen Kleco." & "Yes. This is South field in Kleco." \\
& Panewu & "nggih, O inggih." & \\
\hline
\end{tabular}

The conversation in table 2 happens in Sasana Hondrowina between abdidalem Lurah as locutor and Panewu as interlocutor. The level of madya is used by abdidalem because it gives honour and respect, it seems that the relationship between abdidalem Lurah and Panewu categorized as horizontal relation. It means that, they are the same position. The level of madyacovers niki'this', niku 'that'. Such the example of conversation above can be classified by madya krama. The topic of speaking is asking abdidalem Panewu to help to divide Kirab Malam 1 Sura. Another example of conversation abdidalem used the level of madya can be seen as follows. The following is the conversation between abdidalem Panewu and abdidalem Lurah on informal situation.

Table 3. Conversation in Javanese Madya

\begin{tabular}{llll}
\hline Type & Name & Javanese & English \\
\hline Data 3 & Panewu & "mangga, jenengan nedi riyin." & "please, you eat it at first." \\
& Lurah & "nggih." & "Yes" \\
\hline
\end{tabular}


The example of the conversation in table 3 between abdidalem Panewu as locutor and abdidalem Lurah as interlocutor. The conversation happens in Sasana Hondrowina on informal situation. The level of madya is used by abdidalem because it gives respect between of them. It seems that, the relationship between abdidalem shows horizontal relation. It means that, they are the same position, although, the locutor with high position than the interlocutor. The level of madya consists of nedi'eat', riyin 'at first'. Such the example of the conversation above can be categorized as madya krama. The topic of speaking is asking abdidalem to eat at first.

\section{Krama}

The level of krama is used by a person speaking to another person whose rank of nobility is higher, a person whom the speaker does not know intimately, a person of older age, a person with high reputation or respect, a person who higher social status. The following is the example of the conversation abdidalem Panewu to abdidalem Bupati Anom as follows.

Table 4. Conversation in Javanese Madya

\begin{tabular}{llll}
\hline Type & Name & Javanese & English \\
\hline Data 4 & Panewu & "kaparing matur, mbenjang & "I would tell you come to the \\
& & kadhawuhan sowan kraton badhe & palace because of Grebeg Mulud \\
& & Grebeg Mulud." & tomorrow." \\
& Lurah & "nggih." & "Yes" \\
\hline
\end{tabular}

The conversation in table 4 happens in Sasana Hondrowina on informal situation between abdidalem Panewu as locutor and abdidalem Bupati Anom as interlocutor. The level of krama is used by abdidalem because it gives respect to each other. It shows that the relationship between abdidalem is horizontal relation. The phrase of kaparing matur which is spoken by abdidalem Panewu, it can be indicated that he is a young person than speaker. Such the example of the conversation above is classified by mudha krama, namely abdidalem Panewu, a young person speaks to abdidalem Bupati Anom who is an old person. The topic of speaking is asking abdidalem come to the palace to attend Grebeg Mulud. The following is another the example of the 
conversation between abdidalem Bupati Riyo Inggil and abdidalem Panewu used the level of krama can be illustrated in table 5 .

Table 5. Conversation in Javanese Madya

\begin{tabular}{llll}
\hline Type & Name & Javanese & English \\
\hline Data 5 & Bupati Riyo Inggil & $\begin{array}{l}\text { "Penjenengan dereng mendhet tho } \\
\text { Mas?" }\end{array}$ & "Have you taken it." \\
& Panewu & $\begin{array}{l}\text { "Lha, kala emben sowan mbakErni } \\
\text { kapurihsowan Kangjeng Win." }\end{array}$ & $\begin{array}{l}\text { "yesterday, I visited Erni, she asked } \\
\text { me to visit Kangjeng Win." }\end{array}$ \\
& $\begin{array}{l}\text { Bupati Riyo Inggil } \\
\text { Panewu }\end{array}$ & $\begin{array}{l}\text { "Satunggal wulan meniko" } \\
\text { "nggih." }\end{array}$ & $\begin{array}{c}\text { "A month at the moment } \\
\text { "Yes" }\end{array}$ \\
\hline
\end{tabular}

The conversation in table 5 happens in Sasana Wilapa on formal situation between abdidalem Bupati Riyo Inggil as locutor and abdidalem Panewu as interlocutor. The level of krama is used by abdidalem because it gives respect to each other. It shows that the relationship between abdidalem is horizontal relation although abdidalem Bupati Riyo Inggil who is an old person with high position than abdidalem Panewu. Such the example of the conversation above is classified by wredha krama, namely abdidalem Bupati Riyo Inggil who is an old person speaks to abdidalem Panewu who is a young person. The topic of speaking is abdidalem who asking the salary for a month.

\section{Krama Inggil}

Krama inggil is the lexicon of the level of krama. Krama inggil is used by a person with high reputation. Usually, krama inggil (high krama) is used by the people in the palace. The example of the conversation of abdidalem Bupati Riyo Inggil by using krama inggil in table 6 .

Table 6. Conversation in Javanese Madya

\begin{tabular}{|c|c|c|c|}
\hline Type & Name & Javanese & English \\
\hline \multirow[t]{4}{*}{ Data 6} & Bupati Riyo Inggil & $\begin{array}{l}\text { "sameniko umur penjenengan } \\
\text { pinten Pak?" }\end{array}$ & "How old are you, Sir?" \\
\hline & Bupati Riyo Inggil & $\begin{array}{l}\text { "menawi Jawi } 81 \text { menawi Masehi } \\
\text { 79." }\end{array}$ & $\begin{array}{l}\text { "according to Java is } 81 \text { if Masehi is } \\
\text { 79." }\end{array}$ \\
\hline & Bupati Riyo Inggil & $\begin{array}{l}\text { "pengalaman penjenengan dados } \\
\text { abdidalem wonten kraton meniko } \\
\text { menapa mawon?" }\end{array}$ & $\begin{array}{l}\text { "'what is your experience to be } \\
\text { abdidalem in the palace?" }\end{array}$ \\
\hline & Bupati Riyo Inggil & $\begin{array}{l}\text { "warni-warni pun, ning nyuwun } \\
\text { sewu wonten mriki kaliyan wonten } \\
\text { ksatriyan mboten nate diwedeni } \\
\text { napa diweruhi." }\end{array}$ & $\begin{array}{l}\text { "'a lot of experience, however in } \\
\text { the palace and ksatriyan, I have } \\
\text { never been scared." }\end{array}$ \\
\hline
\end{tabular}




\begin{tabular}{llll}
\hline Type & Name & Javanese & English \\
\hline Bupati Riyo Inggil & $\begin{array}{l}\text { "amargi lampah penjenengan jejek. } \\
\text { Sameniko penjenengan pensiunan." }\end{array}$ & $\begin{array}{l}\text { "because of your manner is } \\
\text { straight. Are you retired?" }\end{array}$ \\
& $\begin{array}{l}\text { "nggih, pensiunan PNS mbolak- } \\
\text { balikejaman, dipun tes lulus } \\
\text { pegawai negeri, dipuntugasaken }\end{array}$ & $\begin{array}{l}\text { "Yes, I retired official government } \\
\text { and passed the examination of it } \\
\text { wonten I worked in Ksatriyan junior }\end{array}$ \\
& $\begin{array}{l}\text { wigh school" } \\
\text { Bupati Riyo Inggil }\end{array}$ & "nggih." & "Yes" \\
\hline
\end{tabular}

The conversation in table 6 happens in Sasana Wilapa on formal situation between abdidalem Bupati Riyo Inggil as locutor and interlocutor. The lexicon of krama inggil is used by abdidalem because it gives respect to each other. The lexicon of krama inggil is affix of dipun and suffix of aken, such as the word dipuntugasaken. It shows that the relationship between abdidalem Bupati Riyo Inggil is horizontal relation. The topic of conversation is experience to be abdidalem in the palace. Its' contain of conversation is speaking of the experience to be abdidalem in the palace.

\section{Kedhaton Language}

Kedhaton language is an exclusive language is used by certain people, situation and place. In other word, kedhaton language is an old language is used in the Surakarta Hadiningrat palace. It is noticed in the manuscript which number of year 1910 is written by a great court poet (pujangga) of Surakarta Hadiningrat palace, namely R.Ng Ranggawarsita entitled Serat Waduaji Tuwin Serat Tatakrami Tembung Kedhaton. The table 7 is quotation of the conversation abdidalem Bupati Riyo Inggil by using kedhaton language on Grebeg ceremony.

Table 7. Conversation in Javanese Madya

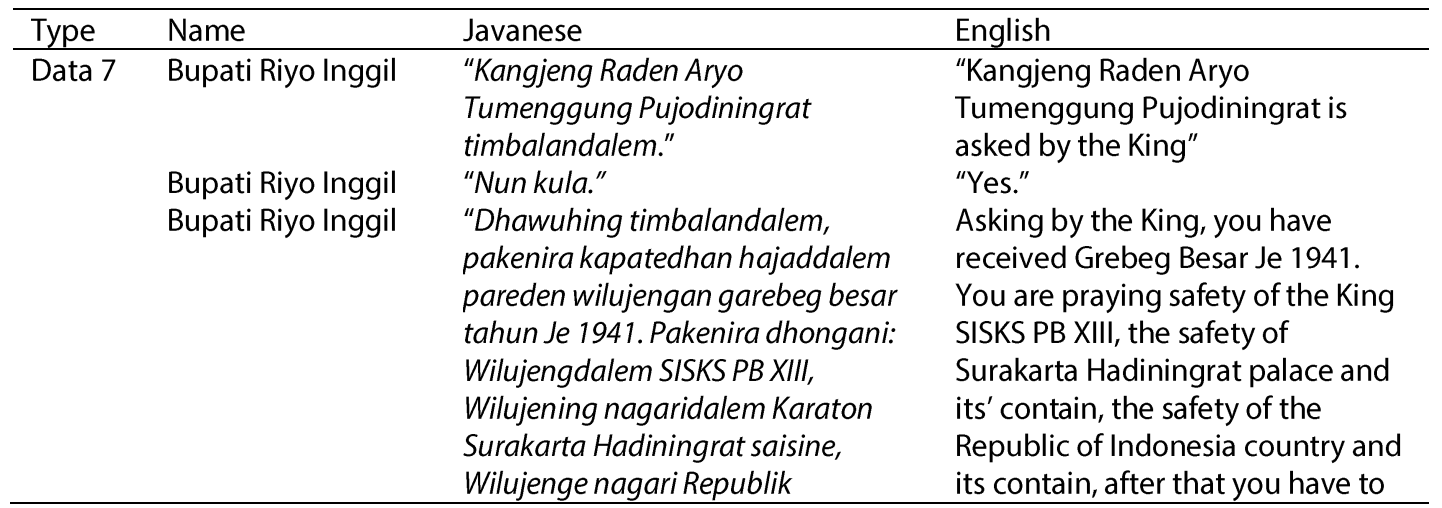




\begin{tabular}{|c|c|c|c|}
\hline Type & Name & Javanese & English \\
\hline & & $\begin{array}{l}\text { Indonesia saisine, yen wus } \\
\text { kadonganan pakenira kadhawuhan } \\
\text { mbage ingkang warata kaya adat. } \\
\text { Nuli tindakna!" }\end{array}$ & divide it as usual. Do it! \\
\hline Data 7 & Bupati Riyo Inggil & $\begin{array}{l}\text { "Kanjeng Raden Aryo Tumenggung } \\
\text { Sumowicitra, abdidalem kawula } \\
\text { sampun hanampi dhawuh } \\
\text { timbalandalem. Dhawuh } \\
\text { timbalandalem, abdidalem kawula } \\
\text { kadhawuhan handongani } \\
\text { wilujengan garebeg besar, } \\
\text { Wilujengipun SISKS PB XIII, } \\
\text { Wilujengipun karatondalem } \\
\text { Surakarta Hadiningrat saisinipun, } \\
\text { Wilujeng rayi-rayi dalem, Wilujening } \\
\text { para sentanadalem, para } \\
\text { abdidalem, Wilujenge nagari } \\
\text { Republik Indonesia seisine, yen wus } \\
\text { kadonganan abdidalem kawula } \\
\text { kadhawuhan mbage ingkang } \\
\text { warata. Atur sembah pamuji kula, } \\
\text { nun inggih sendhika." }\end{array}$ & $\begin{array}{l}\text { "Kangjeng Raden Aryo } \\
\text { Tumenggung Sumowicitro, my } \\
\text { abdidalem have received the duty } \\
\text { of the King. The duty of the King, } \\
\text { my abdidalem have been asked to } \\
\text { pray the safety of grebeg besar, } \\
\text { the safety of SISKS PB XIII, the } \\
\text { safety of Surakarta Hadiningrat } \\
\text { palace and its contain, the safety } \\
\text { of high nobles, the safety of His } \\
\text { Majesty's servant, the safety of } \\
\text { Republic Indonesia country and its } \\
\text { contain, after that my abdidalem } \\
\text { are dividing it as usual. Yes, thank } \\
\text { you so much." }\end{array}$ \\
\hline
\end{tabular}

The conversation in table 7 happens in Agung Mosque on formal situasion. Kedhaton language is used by abdidalem Bupati Riyo Inggil. Abdidalem Bupati Riyo Inggil as the vise of the King as locutor used the level of ngoko, meanwhile the interlocutor used the level of krama. The position of locutor is higher than interlocutor. It seems that, the relationship between locutor and interlocutor is vertical relation. The topic of speaking is Grebeg Besar ceremony.

\section{Bahasa Indonesia}

The use of Javanese language by society in the Surakarta Hadiningrat palace is also affected by code switching or code mixing which is influenced by foreign culture, modernization, experience and knowledge, high education encourage code switching and code mixing. The following is the example of quotation the conversation shows code switching and code mixing by society in the Surakarta Hadiningrat palace as in table 8.

The dialogue in table 8 happens in Kartipradja on formal situation between abdidalem Bupati Riyo Inggil. Javanese is used by abdidalem, however, Indonesia language is also used by abdidalem Bupati Riyo Inggil because he 
had been living a long time in Jakarta so that he cannot much speak in Javanese.

Table 8. Conversation in Javanese Madya

\begin{tabular}{|c|c|c|c|}
\hline Type & Name & Javanese & English \\
\hline \multirow[t]{4}{*}{ Data 8} & Bupati Riyo Inggil & $\begin{array}{l}\text { "jane sing lenggah teng tengah } \\
\text { Gusti Puger nggihGusti Nur jane!" }\end{array}$ & $\begin{array}{l}\text { "a person who is sitting in his } \\
\text { centre of Gusti Puger is Gusti Nur } \\
\text { actually!" }\end{array}$ \\
\hline & Bupati Riyo Inggil & $\begin{array}{l}\text { "masalahnya biasa dibagi dari } \\
\text { parentah kraton pusat." }\end{array}$ & $\begin{array}{l}\text { "the problem is usually divided } \\
\text { from the centre of palace } \\
\text { government." }\end{array}$ \\
\hline & Bupati Riyo Inggil & "napa tho?" & "'What?" \\
\hline & Bupati Riyo Inggil & $\begin{array}{l}\text { "pengageng yogiswara } \\
\text { dhawuhaken ulama." }\end{array}$ & $\begin{array}{l}\text { "the leader of yogiswara asked } \\
\text { ulama" }\end{array}$ \\
\hline
\end{tabular}

\section{Conclusion}

The use of Javanese by society of kraton Surakarta Hadiningrat as follows: related to the relationship between locutor and interlocutor, the form of the use of Javanese by society in the Surakarta Hadiningrat palace at the present is much more different compared to the past. It is caused by the condition of government is the kingdom so that the social status of the kingdom is seemed clearly; the respect attitude to higher social or older person is seemed strongly. It is different from the present; the use of Javanese has been much changed because of the condition is republican so that it has faded from the higher social status to lower social status or the other way. It is influenced by foreign culture, modernization, and high mobility. At the present, the form of the use of Javanese in the palace is horizontal and vertical relation accordance with social status in the palace, namely rank of position, role and age in the palace governmental system. The Javanese forms consist of ngoko, madya, krama, krama inggil, kedhaton language, and even Indonesia language.

\section{References}

Bastiar, Islamiah, et. (2018). Code-Switching in Selling and Buying at Segiri Market, 12(February), 83-88. http://doi.org/10.21512/lc.v12i1.4013

Dwivedi, A. V. (2016). The Register of Games: A Study of the Languages of the Games in India. Dialectologia, 17(September 2014), 151-166.

Erni Zuliana. (2016). Analisis Campur Kode (Mixing Code) Dan Alih Kode (Code Switching) Dalam Percakapan Bahasa Arab, 1(2). 
Fahmee, F., \& Fung, Y. M. (2016). Language choice in online written communication among Maldivian professionals. $3 \mathrm{~L}$ : Language, Linguistics, Literature, 22(2), 49-66. http://doi.org/10.17576/3L-2016-2202-04

Fithriyah Nurunnisa' Al. (1993). Variasi Bahasa Pada Dialog Film Red Cobex: Kajian Sosiolinguistik. Skriptorium, 1(2), 81-93.

Hymes, D. (1974). Foundations in Sociolinguistics: An Ethnograpic Approach. Philladelphia: University of Pensylvenia Press.

Marlina Maros, et al. (2016). Code Switching as the Medium of Solidarity in 'Ola Bola'. Jurnal Komunikasi, 32(2), 1-28.

Poedjosoedarmo, S. (1979). Tingkat Tutur Bahasa Jawa. Jakarta: Depdikbud.

Yusuf, Y. Q., Fata, I. A., \& Chyntia. (2018). Types of Indonesian-English codeswitching employed in a novel. Kasetsart Journal of Social Sciences, 2-7. http://doi.org/10.1016/j.kjss.2018.02.004 